\title{
ANALISIS POLA KEMITRAAN AGRIBISNIS DI KAMPUNG KUCAI, DUSUN KRANGGAN, KECAMATAN GARUM, KABUPATEN BLITAR
}

\author{
${ }^{1)}$ Lintar Brillian Pintakami, ${ }^{2)}$ Muttia Yan Asdasiwi \\ ${ }^{1)}$ Dosen Fakultas Pertanian, Universitas Islam Balitar Blitar \\ ${ }^{2)}$ Mahasiswa Fakultas Pertanian, Universitas Islam Balitar Blitar \\ Email : ${ }^{1}$ lintar.brillian@gmail.com
}

\begin{abstract}
This study aims to provide an overview of the form of agribusiness partnership patterns that take place in Kampung Kucai, as well as analyzing the perceptions of peasant partners in the partnership program. In addition, this study shows whether there are differences in income received by partner farmers and non-partner farmers. The method of determining respondents in this study uses cluster sampling. From the calculation results obtained by the number of samples for Non-Partner farmers as many as 44 farmers. While the sample used for Kucai Mitra farmers was 20 people. In addition there are also 5 key informants Data collection methods carried out in this study there are several kinds of structured interviews, in-depth interviews, participatory observation, and documentation. Data analysis using descriptive analysis, Likert analysis, farming analysis, and statistical analysis of average difference test. The results showed that the type of partnership between the "BRI Bank" Financial Institution and partner chives farmers was classified as a core-plasm partnership pattern. The perception of partner chives farmers to the partnership process with the financial institution "Bank BRI" which has a very good category with a percentage of $80 \%$ where the total score is 483 . The results of income obtained by partner chives farmers are greater than independent chives farmers, amounting to Rp. 435,075, - / harvest for partner farmers, while independent farmers in the amount of Rp.305,783, - / harvest. The results of the statistical test of the average difference showed that the value of t hit Equal variances not assumed 5.059> 0.05 then HA was accepted and H0 was rejected, so it could be said that there was a significant difference between the income of partners and independent farmers.
\end{abstract}

Keywords: Kampung Kucai, Partnership, Perception, Income

\section{PENDAHULUAN}

Data Badan Pusat Statistik tahun 2018 menjelaskan bahwa sisa luas lahan pertanian tinggal 7,1 juta hektar dibanding tahun sebelumnya yang masih 7,75 juta hektar (CNN Indonesia, 2018). Melihat kondisi tersebut dimana pertanian masih menjadi sektor utama untuk masyarakat, maka diperlukan suatu usaha strategis dan inovatif sebagai tindakan kreatif dalam usaha agribisnis (Pintakami, 2018). Salah satu tindakan agribisnis kreatif yaitu melalui pemanfaaatn pekarangan rumah tangga (Yulida, 2013).

Ashari (2012) menyatakan pemanfaatan lahan pekarangan yang berada di sekitar rumah jika dikembangkan secara baik akan dapat bermanfaat lebih jauh lagi, seperti memberikan tambahan pendapatan ekonomi. Salah satu komoditi yang mudah di budidayakan dalam lahan pekarangan dan memiliki nilai ekonomis yaitu kucai (Paeru R.H, 2015). Kucai (Allium tuberosum) juga merupakan salah satu tanaman kearifan lokal di Jawa Timur, yang dapat tumbuh dan berkembang di daerah iklim tropis.

Dusun Kranggan yang berada di Desa Pojok, Kabupaten Blitar pada tahun 2017 ditetapkan sebagai lokasi percontohan budidaya Kucai intensif dengan memanfaatkan 
Lintar Brillian Pintakami \& Muttia Yan Asdasiwi, 2020. Analisis Pola Kemitraan Agribisnis Di Kampung Kucai, Dusun Kranggan, Kecamatan Garum, Kabupaten Blitar.

Journal Viabel Pertanian. (2020), 14(1)21-36

lahan pekarangan sehingga mendapat sebutan sebagai Kampung Kucai. Sebagai upaya dalam meningkatkan kapasitas produksi kucai, petani yang tergabung dalam kelompok tani di Kampung Kucai memiliki program kemitraan dengan lembaga keuangan "Bank BRI". Peran kemitraan di kampung kucai ini sangat membantu dalam pendanaan terhadap usahatani kucai. Menurut Bitzer, V., dkk (2012) kegiatan kemitraan di negara-negara berkembang secara umum memiliki tujuan untuk meningkatkan mata pencaharian pedesaan, serta membentuk kapasitas petani-petani kecil.

Program kemitraan dapat berjalan dengan baik bergantung pada sikap peserta mitra, seperti mematuhi segala persyaratan dan komitmen terhadap perjanjian yang dibuat antara kedua belah pihak maka akan semakin baik pula program kemitraan yang terjalin (Wahyu, 2010). Berdasarkan informasi dari survei pendahuluan, menunjukkan bahwa belum semua petani mitra di Kampung Kucai paham terhadap isi perjanjian kontrak kerjasama kemitraan. Sehingga hal ini menarik untuk dikaji, tentang bagaimana persepsi petani mitra terhadap proses kemitraan dengan Lembaga Keuangan "Bank BRI".

Petani yang mengikuti program kemitraan di Kampung Kucai beranggapan bahwa dengan mengikuti kemitraan pendapatan yang diterima akan lebih tinggi daripada menjadi petani non- mitra. Sedangkan untuk petani yang tidak menjalin kemitraan beranggapan bahwa menjadi petani non- mitra lebih bebas dalam menjalankan usahataninya, tidak terikat dengan aturan yang ditetapkan oleh Lembaga Keuangan "Bank BRI". Adanya gambaran karakteristik yang berbeda antara petani kucai mitra dan nonmitra tersebut, tentunya menimbulkan perbedaan pendapatan pada masing-masing petani kucai (mitra dan non- mitra). Sehingga dalam penelitian ini penting untuk membandingkan pendapatan antara petani mitra dan non- mitra.

Penelitian ini sangat penting dilakukan untuk memberikan gambaran tentang bentuk pola kemitraan agribisnis yang berlangsung di Kampung Kucai, serta menganalisis tentang persepsi petani kucai mitra terhadap program kemitraan. Selain itu, penelitian ini menunjukkan apakah terdapat perbedaan pendapatan yang diterima petani mitra dengan petani non- mitra.

\section{RUMUSAN MASALAH} berikut:

Adapun rumusan masalah yang akan dibahas dalam penelitian ini adalah sebagai

1. Bagaimana pola kemitraan yang dilakukan oleh lembaga keuangan "Bank BRI" dengan petani mitra di Kampung Kucai?

2. Bagaimana persepsi petani kucai mitra terhadap proses kemitraan dengan lembaga keuangan "Bank BRI"?

3. Apakah terdapat perbedaan pendapatan usahatani antara petani kucai mitra dengan petani kucai non- mitra di daerah penelitian?

\section{TUJUAN PENELITIAN}

Tujuan penelitian ini untuk mendeskripsikan pola kemitraan yang dilakukan oleh lembaga keuangan "Bank BRI" dengan petani mitra di Kampung Kucai dan menganalisis persepsi petani mitra terhadap proses kemitraan dengan lembaga keuangan tersebut serta membandingkan perbedaan pendapatan usahatani antara petani kucai mitra dengan petani kucai non- mitra di daerah penelitian. 
Lintar Brillian Pintakami \& Muttia Yan Asdasiwi, 2020. Analisis Pola Kemitraan Agribisnis Di Kampung Kucai, Dusun Kranggan, Kecamatan Garum, Kabupaten Blitar.

Journal Viabel Pertanian. (2020), 14(1)21-36

\section{TINJAUAN PUSTAKA}

\section{Definisi Kemitraan}

Kemitraan Agribisnis merupakan potensi modernisasi bagi sektor pertanian yang menawarkan banyak keuntungan dalam kontirbusi terhadap pembangunan pertanian berkelanjutan, dimana petani-petani kecil akan banyak terlibat (Rankin, M., dkk. 2016). Kemitraan merupakan solusi win-win yang akan mendukung pertumbuhan inklusif, memberdayakan petani kecil, dan membentuk rantai nilai yang efisien (Gregoratti, C. 2011).

Kemitraan merupakan kesepakatan kolaboratif yang dilembagakan antar pelaku usaha dari dua sektor atau lebih yang bertujuan untuk mendukung produksi dan/atau perlindungan terhadap barang (Schaferhoff, M., dkk. 2009). Untuk mencapai tujuan bersama, kemitraan mengimplementasikan beberapa aktivitas pada tingkat produksi untuk mendukung petani dengan pengetahuan dan sumber daya. Petani dapat dijangkau oleh organisasi perodusen yang ada, atau didukung untuk membentuk organisasi produsen sendiri.

Dengan demikian, kemitraan mencerminkan pentingnya organisasi produsen dalam kerjasama pembangunan sebagai instrumen dalam mendorong pembangunan pedesaan dan memfasilitasi keikutsertaan petani kecil ke dalam pasar. Kemitraan terbentuk berdasarkan pemikiran aksi kolektif untuk memenuhi fungsi ekonomis terkait produksi, proses, dan pemasaran agribisnis, dan juga fungsi non-profit, seperti pembangunan kapasitas, pendidikan, dan advokasi. Potensi dari kemitraan tidak hanya sebatas pada dukungan finansial. Peningkatan posisi petani terhadap pasar juga relevan, misalnya dalam membangun koneksi langsung terhadap pembeli secara luas. Kegiatan kemitraan di antara negara-negara berkembang secara umum memiliki tujuan untuk menstabilkan standarisasi produksi, meningkatkan mata pencaharian pedesaan, serta membentuk kapasitas petani-petani kecil (Bitzer, V., dkk. 2012).

\section{Pola Kemitraan Agribisnis}

\section{a. Pola Kemitraan Inti-Plasma}

Pola ini menempatkan perusahaan sebagai inti, yang bertugas untuk menyediakan lahan, penyiapan sarana produksi, pemberian bimbingan, manajemen, menampung, dan mengelolah, serta memasarkan hasil produksi. Sedangkan yang bertindak sebagai plasma adalah petani atau kelompok tani sebagai mitra.

\section{b. Pola Kemitraan Sub-Kontrak}

Pola ini memposisikan kemitraaan antara kelompok mitra usaha dan perusahaan yang menghasilkan output yang diperlukan perusahaan mitra sebagai bagian dari produksinya.

\section{c. Pola Kemitraan Dagang Umum}

Kemitraan dagang umum adalah pola kemitraan yang terdapat sebuah hubungan usaha dalam hasil pemasaran produksi. Adapun pihak- pihak yang terlibat adalah pihak pemasaran dengan kelompok usaha pemasok komoditas yang diperlukan oleh pihak pemasaran tersebut. 
Lintar Brillian Pintakami \& Muttia Yan Asdasiwi, 2020. Analisis Pola Kemitraan Agribisnis Di Kampung Kucai, Dusun Kranggan, Kecamatan Garum, Kabupaten Blitar. Journal Viabel Pertanian. (2020), 14(1)21-36

\section{d. Pola Kemitraan Keagenan}

Yaitu merupakan suatu hubungan kemitraan yang terjalin antara dua pihak atau lebih dimana kelompok mitra diberikan hak secara khusus untuk dapat memasarkan suatu barang/jasa usaha yang dimiliki oleh perusahaan mitra.

\section{e. Pola kemitraan kerja sama operasional agribisnis (KOA)}

Pola kemitraan kerja sama operasional agribisnis merupakan sebuah hubungan kemitraan dimana peserta mitra menyediakan lahan, tenaga kerja, dan sarana. Sedangkan pihak perusahaan mitra menyediakan biaya, modal, manajemen, dan pengadaan sarana produksi untuk mengusahakan atau membudidayakan suatu komoditas pertanian. Di samping itu, yang membuat pola kemitraan KOA ini berbeda dengan pola kemitraan yang lain yaitu perusahaan mitra berperan sebagai penjamin pasar produk melalui peningkatan nilai tambah produk melalui pengolahan, pengemasan, atau usaha lainnya (Lestari, 2009).

\section{Pengertian Persepsi}

Persepsi menurut Theodorson (dalam Pintakami, 2013) merupakan interprestasi dari seseorang terhadap pesan yang diberikan. Persepsi dipengaruhi oleh proses belajar, aktivitas, kebutuhan, pengalaman dan lain-lain. Persepsi merupakan pengalaman tentang obyek, peristiwa atau hubungan-hubungan yang diperoleh dengan menyimpulkan informasi dan menafsirkan pesan. Persepsi adalah inti komunikasi, sedangkan penafsiran (interpretasi) adalah inti persepsi, yang identik dengan penyandian balik (decoding) dalam proses komunikasi. Berdasarkan definisi-definisi di atas, persepsi dapat diartikan sebagai suatu proses penafsiran dan menyimpulkan pesan dari suatu obyek yang diterima oleh indera dan dapat mempengaruhi pemikiran serta dapat membentuk sikap seseorang.

Persepsi dibagi menjadi 2 macam yaitu persepsi positif dan negatif. Persepsi positif apabila penilain terhadap obyek memiliki kesan baik, dan sebaliknya jika penilaian terhadap obyek tidak baik maka termasuk persepsi negatif (Dahniar, 2011). Sehingga dapat disimpulkan bahwa persepsi merupakan pengalaman tentang obyek, peristiwa atau hubungan-hubungan yang didapatkan dengan menyimpulkan informasi dan menafsirkan pesan yang diterima. Persepsi mempunyai pengaruh yang sangat besar dalam menentukan sikap seseorang terhadap suatu stimulus. Persepsi yang salah akan menimbulkan sikap yang menyimpang dari apa yang diharapkan oleh komunikator. Sehingga untuk mengubah persepsi seseorang dimulai dengan upaya dan teknik untuk mempengaruhi persepsi orang tersebut terhadap pesan dan informasi-informasi.

\section{Analisis Usahatani}

Usahatani adalah kegiatan usaha manusia untuk mengusahakan tanahnya dengan maksud untuk memperoleh hasil tanaman atau hewan tanpa mengakibatkan berkurangnya kemampuan tanah yang bersangkutan untuk memperoleh hasil selanjutnya. Usahatani dilaksanakan agar petani memperoleh keuntungan secara terus menerus dan bersifat komersial (Dewi, 2012).

\section{Biaya Usahatani}

Biaya adalah suatu nilai tukar, pengeluaran atau pengorbanan yang dilakukan untuk menjamin perolehan manfaat (Carter dan Usry, 2009). Berdasarkan Standar Akuntansi Keuangan (2014) "Biaya adalah pengeluaran kas (atau setara kas) yang dibayarkan atau sebesar nilai wajar dari imbalan (consideration) yang diberikan untuk memperoleh aset pada saat perolehan.” 
Lintar Brillian Pintakami \& Muttia Yan Asdasiwi, 2020. Analisis Pola Kemitraan Agribisnis Di Kampung Kucai, Dusun Kranggan, Kecamatan Garum, Kabupaten Blitar. Journal Viabel Pertanian. (2020), 14(1)21-36

Terdapat pengklasifikasian biaya dalam usahatani, pengklasifikasian biaya tersebut digunakan untuk memudahkan dalam menghitung beban pokok produksi atau menentukan titik impas penjualan produk usahatani. Berdasarkan pola perilaku biaya, Kuswadi (dalam Wati, 2017) mengklasifikasikan jenis-jenis biaya menjadi :

\section{a. Biaya Tetap (fixed cost)}

Merupakan biaya yang jumlahnya tetap tidak dipengaruhi oleh kuantitas produksi. Komponen biaya tetap usahatani antara lain : pajak tanah, pajak air,bangunan pertanian, penyusutan, dan lain sebagainya.

Rumus :

$\mathrm{FC}=\mathrm{Px} \cdot \mathrm{X}$

Keterangan :

FC : Biaya tetap (Fixed cost)

Px : Harga Input

$\mathrm{X}:$ Jumlah Input

\section{b. Biaya Variabel (variable cost)}

Adalah sebuah biaya yang jumlahnya berubah- ubah sesuai dengan kapasitas produksi. Contoh biaya variabel yaitu : biaya untuk pupuk, bibit, pestisida, tenaga kerja, biaya panen dan sebagainya.

Rumus :

$\mathrm{VC}=\mathrm{TC}-\mathrm{FC}$

Keterangan :

VC : Biaya variabel

TC : Total biaya

FC : Biaya tetap

\section{Penerimaan Usahatani}

Pengertian penerimaan usahatani adalah perkalian antara volume produksi yang diperoleh dengan harga jual (Soekartawi, 2012). Harga jual adalah harga transaksi antara produsen dan pembeli untuk setiap komoditas. Satuan yang digunakan seperti satuan yang lazim digunakan antara penjual/pembeli secara partai besar, misalnya: kilogram (kg), kuintal (kw), ton, ikat, dan sebagainya. Penerimaan dapat dirumuskan sebagai berikut:

$\mathrm{TR}=\mathrm{Q} \times \mathrm{P}$

Dimana:

TR $($ Total Revenue $)=$ Penerimaan usaha

Q (Quantity) $=$ Produk yang dihasilkan

$\mathrm{P}($ Price $)=$ Harga jual produk yang dihasilkan

\section{Pendapatan Usahatani}

Menurut Soekartawi (2012), pendapatan adalah selisih antara penerimaan dan biaya pengeluaran, secara sistematis dapat ditulis:

$\pi=\mathrm{TR}-\mathrm{TC}$

Keterangan:

$\pi=$ pendapatan atau keuntungan

$\mathrm{TR}=$ total penerimaan

$\mathrm{TC}=$ total biaya 


\section{METODE PENELITIAN}

Penentuan lokasi penelitian dilakukan secara purposif yaitu di Kampung Kucai, Dusun Kranggan, Desa Pojok, Kabupaten Blitar. Pertimbangan penentuan lokasi penelitian tersebut karena seluruh masyarakat secara intensif melakukan usahatani kucai di lahan pekarangan. Selain itu, di daerah tersebut diketahui terdapat petani kucai yang terlibat dalam program kemitraan dengan Lembaga Keuangan "Bank BRI". Penelitian dilaksanakan mulai dari bulan Agustus 2019 sampai Februari 2020.

Responden dalam penelitian ini adalah petani kucai mitra dan petani kucai nonmitra yang berada di Kampung Kucai. Teknik pengambilan sampling yang digunakan adalah Cluster Sampling. Pertimbangannya sebab populasi menyebar sangat luas dan bersifat heterogen. Hasil lapang menunjukkan populasi petani kucai yaitu 100 orang yang terdiri dari petani Kucai Mitra sebanyak 20 orang dan petani Kucai Non- Mitra sebanyak 80 orang. Penentuan jumlah sampel pada petani Kucai Non-Mitra ditentukan menggunakan rumus Slovin, sebab adanya faktor keterbatasan waktu, biaya, dan tenaga (Amirin, 2011), dengan tingkat kekeliruan pengambilan sampelsebesar 10\%. Sehingga didapatkan jumlah sampel untuk petani Non- Mitra sebanyak 44 petani. Sedangkan sampel yang digunakan untuk petani Kucai Mitra adalah sejumlah keseluruhan total populasi 20 orang. Seluruh populasi menjadi sampel karena dalam menghadapi populasi yang terlalu kecil maka seorang peneliti akan lebih baik bila seluruh anggota populasi dijadikan sampelnya, semua diteliti dan hasilnya pasti akan bisa menggambarkan karakter populasi secara persis (Sutopo, 2018). Selain 64 responden petani kucai, juga terdapat 5 key informan guna melengkapi hasil penelitian ini, terdiri dari : Kepala Dusun, Pegawai Lembaga Keuangan Bank BRI, serta Ketua Kelompok Tani Al- Alfiah, An- Nisa, dan Manfaat.

Pengambilan data primer dilakukan dengan cara wawancara terstruktur dengan seluruh sampel petani Kucai Mitra dan untuk petani Kucai Non- Mitra, wawancara mendalam (in- depth interview) kepada Kepala Dusun, Pegawai Lembaga Keuangan Bank BRI, serta Ketua Kelompok Tani Al- Alfiah, An- Nisa, dan Manfaat, dan observasi partisipatif dimana obyek yang diobservasi adalah proses kemitraan antara petani kucai mitra dengan lembaga keuangan "Bank BRI".Sedangkan data sekunder yang diperlukan antara lain profil desa/ dusun, profil kelompok tani kucai, data administrasi kelompok tani, kontrak kerjasama kemitraan.

Metode analisis data yang dipakai dalam penelitian ini adalah analisis deskriptif, analisis likert, dan analisis kuantitatif. Analisis deskriptif digunakan untuk menguraikan secara deskripif menggunakan kalimat yang akurat sesuai dengan fakta- fakta serta fenomena yang terjadi yang berkaitan dengan pola kemitraan agribisnis antara lain bentuk pola kemitraan, pelaksanaan kemitraan, serta hak dan kewajiban petani kucai mitra dan Lembaga Keuangan "Bank BRI".Analisis Likert digunakan untuk menganalisis persepsi petani kucai mitra terhadap proses kemitraan dengan lembaga keuangan "Bank BRI". Analisis kuantitatif yang digunakan terdiri dari analisis usahatani dan uji beda rata- rata. 


\section{Analisis Usahatani}

$$
\begin{array}{ll}
\text { a. } \text { Analisis Biaya } \\
\text { TC }=\text { TFC + TVC } \\
\begin{array}{cl}
\text { Dimana : } & \\
\text { TC } & \text { Biaya Total } \\
\text { TFC } & =\text { Biaya Tetap } \\
\text { TVC } & =\text { Biaya Variabel }
\end{array}
\end{array}
$$

\section{b. Analisis Penerimaan}

$\mathrm{TR}=\mathrm{Y} . \mathrm{P}_{\mathrm{y}}$

Dimana:

$\mathrm{TR}=$ Total penerimaan;

Y = Produksi yang diperoleh dalam usahatani;

$\mathrm{P}_{\mathrm{y}} \quad=$ Harga penjualan hasil produksi

\section{c. Analisis Pendapatan}

$$
\eta=\mathrm{TR}-\mathrm{TC}
$$

Dimana:

$$
\begin{array}{ll}
\eta & =\text { Pendapatan usaha tani } \\
\mathrm{TR} & =\text { Total penerimaan; } \\
\mathrm{TC} & =\text { Total biaya }
\end{array}
$$

\section{Analisis Uji Beda Rata- Rata}

Analisis ini digunakan untuk mengetahui apakah terdapat perbedaan pendapatan antara petani Kucai Mitra dan petani Kucai Non- Mitra. Menurut Imam (dalam Pintakami, 2013) Alat uji statistik yang cocok untuk melihat hubungan antara variabel tergantung dari jumlah kategori dari variabel, jika variabel berkategori dua maka uji statistik yang digunakan adalah uji beda rata-rata. Uji beda rata-rata digunakan untuk menentukan apakah dua sampel yang tidak berhubungan memiliki nilai rata-rata yang berbeda.

\section{Profil Lokasi Penelitian}

\section{HASIL DAN PEMBAHASAN}

Desa Pojok merupakan salah satu desa di kecamatan garum dari sembilan desa yang ada di Kecamatan Garum, Kabupaten Blitar, dengan batas-batas wilayah sebagai berikut :

a. Sebelah Utara berbatasan dengan desa jiwut, kecamatan nglegok.

b. Sebelah Selatan berbatasan dengan desa papungan dan kelurahan gedog, kecamatan kanigoro dan sananwetan.

c. Sebelah Barat berbatasan dengan Kel.Gedog dan Kel.Sentul, kecamatan sananwetan dan Kepanjenkidul.

Kondisi geografis menunjukkan Desa Pojok merupakan daerah yang sebagian besar wilayahnya mengandalkan sektor pertanian. Lahan yang digunakan untuk memproduksi hasil pertanian ini mencapai 29 Ha pada tahun 2018 yang belum termasuk dalam sektor perikanan, perkebunan, kehutanan, dan peternakan. Jumlah penduduk di desa Pojok pada tahun 2018mencapai 10.157 jiwa. Adapun tingkat pertumbuhan pertumbuhan penduduk di desa pojok mencapai $0,29 \%$ untuk penduduk laki-laki dan $0,09 \%$ untuk penduduk perempuan.Keadaan penduduk menurut mata pencaharian di desa pojok terbagi menjadi enam sektor antara lain di bidang pertanian terdapat 1.554 orang yang menekuni dibidang tersebut. Di bidang peternakan terdapat 45 orang, dibidang 
Lintar Brillian Pintakami \& Muttia Yan Asdasiwi, 2020. Analisis Pola Kemitraan Agribisnis Di Kampung Kucai, Dusun Kranggan, Kecamatan Garum, Kabupaten Blitar.

Journal Viabel Pertanian. (2020), 14(1)21-36

industri kecil terdapat 364 orang, di bidang industri menengah dan besar terdapat 300 orang, di bidang perdagangan terdapat 1.113 orang, di bidang jasa terdapat 2.063.

\section{Gambaran Umum Kelompok Tani Kucai di Desa Pojok}

Kelompok tani kucai merupakan suatu kelompok tani yang anggotanya diwajibkan untuk menanam kucai berada di desa Pojok, Garum, Kabupaten Blitar. Kelompok tani kucai bergerak dengan memanfaatkan lahan sempit yang berada di desa Pojok. Kelompok tani ini tergabung dari dua kelompok tani wanita yang ada di desa Pojok yaitu Kelompok Tani Al Fiah dan Kelompok Tani An Nisa'.Dalam membudidayakan kucai ini para anggota kelompok tani menanamnya di lahan pekarangan rumah untuk memanfaatkan lahan pekarangan.

Kelompok tani kucai ini awalnya adalah gabungan dari dua kelompok tani di dusun kranggan, desa pojok, Kecamatan Garum Kab. Blitar. Berawal dari salah satu kelompok tani yang menanam buah strowberi di lahan pekarangan, namun karna cuaca yang tidak mendukung sehingga berganti menanam kucai yang menurut mereka lebih mudah dalam perawatannya dan lebih cepat panennya, sehingga kelompok tani lain ingin bergabung dan membudidayakan kucai di dusun Kranggan. Lalu terbentuklah kelompok tani kucai yang terdiri dari anggota kelompok tani Al Afiah dan An Nisa'. Setelah kedua kelompok tani tersebut bergabung setiap anggota kelompok tani di wajibkan untuk menanam kucai yang hasilnya akan di pasarkan di Blitar. Awalnya bibit kucai mengambil dari kota lain, namun berjalannya waktu petani kucai mampu membudidayakannya sendiri. Setelah berjalan secara mandiri kelompok tani kucai tersebut mendapat bantuan dari lembaga keuangan "Bank BRI" dan pemasaran kucai di kampung kucai tersebut di urus oleh 8 induk.

\section{Pola Kemitraan Kampung Kucai}

Kemitraan oleh Kelompok Tani kucai dengan lembaga keuangan "Bank BRI" mulai diterapkan pada tahun 2018. Awalnya salah satu kelompok tani di daerah Kranggan memiliki kegiatan menanam sayuran melalui pemanfaatan pekarangan rumah. Hingga tahun 2013 kelompok tani tersebut mengajukan bantuan pada Lembaga Keuangan "Bank BRI". Hubungan kemitraan yang terjalin antara lembaga keuangan "Bank BRI" dengan petani kucai mitra ini menguntungkan kedua belah pihak, karena melalui program kemitraan ini Bank BRI akan mendapatkan penambahan nasabah untuk menggunakan jasa lembaga keuangan tersebut. Sedangkan untuk petani kucai mitra mendapatkan keuntungan dalam hal tersedianya pinjaman untuk proses usahatani.Berdasarkan jenisnya kemitraan yang berlangsung di Lembaga keuangan "Bank BRI" termasuk kemitraan vertikal, dikarenakan hubungan kerjasama ini terintegrasi secara langsung antara petani kucai mitra dengan Lembaga keuangan "Bank BRI". Hubungan langsung tersebut meliputi kegiatan pengajuan bantuan keuangan, pelaksanaan kegiatan usahatani, pembinaan, pengawasan, pelayanan jasa keuangan, dan pengajuan kerjsama kembali. Menurut Lestasi (2009)kemitraan vertikal terbagi dalam beberapa pola kemitraan antara lain : Pola inti plasma, Pola Sub kontrak, Poladagang umum, dan Pola Waralaba/Keagenan. Berdasarkan Surat Keputusan (SK) Menteri Pertanian No.940/Kpts/OT.210/10/1997 tentang Pedoman Kemitraan Usaha Pertanian, jenis kemitraan antara Lembaga keuangan "Bank BRI" dengan petani kucai mitra tergolong pola kemitraan inti-plasma.

Pola kemitraan inti- plasma adalah pola kemitraan yang melibatkan hubungan petani mitra sebagai plasma dengan perusahaan sebagai inti yang bermitra usaha. Perusahaan inti mempunyai kewajiban untuk menyediakan sarana produksi, bimbingan teknis, dan manajemen produksi usahatani. Sementara itu kelompok mitra bertugas 
Lintar Brillian Pintakami \& Muttia Yan Asdasiwi, 2020. Analisis Pola Kemitraan Agribisnis Di Kampung Kucai, Dusun Kranggan, Kecamatan Garum, Kabupaten Blitar. Journal Viabel Pertanian. (2020), 14(1)21-36

memenuhi kebutuhan perusahaan inti sesuai dengan persyaratan yang telah disepakati. Pada proses kemitraan yang terjadi di kampung kucai, yang berperan sebagai pihak inti adalah Lembaga keuangan "Bank BRI" sebagai inti yang memberikanbantuan berupa benih, alat, pupuk, dan penyuluhan.Sedangkan petani kucai mitraberperan sebagai plasma, yakni menyediakan lahan, dan tenaga kerja. Berikut beberapa ketentuan yang di lakukan Kelompok Tani Kucai dengan lembaga keuangan "Bank BRI" :

1. Petani dari Kelompok tani kucai akan mendapat bantuan jika memiliki surat keterangan tidak mampu.

2. Petani harus memiliki tabungan dari hasil panennya selama sebulan

3. Dalam setahun petugas "Bank BRI" memberikan pembimbingan kepada petani mitra

4. Jika sudah mencapai satu tahun bantuan dari Bank BRI sudah menjadi hak milik petani mitra.

Dalam mekanisme pola kemitraan Lembaga Keuangan "Bank BRI" dengan Kelompok Tani Kucai dilakukan dengan berdasarkan perjanjian kemitraan. Dalam surat perjanjian terdapat identitas kedua belah pihak yang bermitra dan aturan-aturan yang diberikan "Bank BRI" serta lokasi atau daerah penanaman. Dalam surat perjanjian tersebut, juga mencakup kesepakatan tanaman komoditas serta kewajiban yang di jalankan oleh Lembaga keuangan dan petani mitra. Ada beberapa kewajiban yang harus Lembaga keuangan Bank BRI dan petani mitra lakukan, antara lain menyusun data lahan-lahan yang akan bermitra dengan "Bank BRI", memberikan bantuan berupa benih, pupuk, dan alat pertanian, serta memberikan pembinaan kepada petani mitra. Kewajiban untuk petani mitra yaitu memiliki tabungan hasil panennya dalam satu bulan.

\section{Persepsi Petani KucaiTerhadap Proses Kemitraan Dengan Lembaga Keuangan "Bank BRI"}

Persepsi petani kucai mitramemberikan gambaran penafsiran petani terhadap proses kemitraan. Terdapat tiga hal yang dinilai dalam persepsi petani mitra, yaitu perencanaan proses kemitraan, pelaksanaan proses kemitraan, dan evaluasi proses kemitraan. Beberapa komponen dalam penilaian persepsi diberikan untuk mengetahui sejauh mana proses kemitraan berlangsung antara petani kucai mitra dengan Lembaga Keuangan "BRI". Penilaian persepsi ini diharapkan menjadi pemacu agar proses kemitraan berjalan dengan lebih baik lagi. Jika terdapat perbedaan persepsi maka masuk ke dalam penilaian obyek persepsi yang positif dan atau persepsi yang negatif (Dahniar, 2011). Adapun persepsi petani kucai mitra terhadap proses kemitraan dapat terlihat pada tabel 1 berikut ini : 
Lintar Brillian Pintakami \& Muttia Yan Asdasiwi, 2020. Analisis Pola Kemitraan Agribisnis Di Kampung Kucai, Dusun Kranggan, Kecamatan Garum, Kabupaten Blitar. Journal Viabel Pertanian. (2020), 14(1)21-36

Tabel 1. Persepsi Petani Kucai Mitra TerhadapProses Kemitraan

\begin{tabular}{|c|c|c|c|c|}
\hline No. & Indikator & Jumlah & Persentase & Kategori \\
\hline \multicolumn{5}{|c|}{ Perencanaan Proses Kemitraan } \\
\hline 1. & $\begin{array}{l}\text { Proses kemitraan usahatani kucai dengan } \\
\text { pihak Lembaga Keuangan "Bank BRI" }\end{array}$ & 48 & $80 \%$ & Sangat baik \\
\hline 2. & $\begin{array}{l}\text { Target yang diberikan pihak Lembaga } \\
\text { Keuangan "Bank BRI" }\end{array}$ & 48 & $80 \%$ & Sangat baik \\
\hline 3. & $\begin{array}{l}\text { Prosedur pengajuan kemitraan dengan } \\
\text { pihak Lembaga Keuangan "Bank BRI" }\end{array}$ & 48 & $80 \%$ & Sangat baik \\
\hline \multicolumn{5}{|c|}{ Proses Kemitraan } \\
\hline 4. & $\begin{array}{l}\text { Bantuan yang di berikan pihak Lembaga } \\
\text { Keuangan "Bank BRI" }\end{array}$ & 48 & $80 \%$ & Sangat baik \\
\hline 5. & $\begin{array}{l}\text { Pembinaan dari Lembaga Keuangan } \\
\text { "Bank BRI" }\end{array}$ & 45 & $75 \%$ & Cukup baik \\
\hline 6. & $\begin{array}{l}\text { Hasil produksi sesuai target dari pihak } \\
\text { Lembaga Keuangan "Bank BRI" }\end{array}$ & 46 & $77 \%$ & Cukup baik \\
\hline 7. & $\begin{array}{l}\text { Pendapatan yang diperoleh setelah } \\
\text { bermitra dengan Lembaga Keuangan } \\
\text { "Bank BRI", }\end{array}$ & 48 & $80 \%$ & Sangat baik \\
\hline \multicolumn{5}{|c|}{ Evaluasi Proses Kemitraan } \\
\hline 8. & $\begin{array}{l}\text { Pengawasan Lembaga Keuangan "Bank } \\
\text { BRI" }\end{array}$ & 48 & $80 \%$ & Sangat baik \\
\hline 9. & $\begin{array}{l}\text { Pelayanan Lembaga Keuangan "Bank } \\
\text { BRI" }\end{array}$ & 52 & $87 \%$ & Sangat baik \\
\hline 10. & $\begin{array}{l}\text { Kerjasama dengan Lembaga Keuangan } \\
\text { "Bank BRI" }\end{array}$ & 52 & $87 \%$ & Sangat baik \\
\hline & TOTAL & 483 & $80 \%$ & Sangat baik \\
\hline
\end{tabular}

Sumber : Data Primer Diolah, 2020

Persepsi petani kucai mitra terhadap perencanaan proses kemitraan dengan lembaga keuangan "Bank BRI" yang memiliki kategori sangat baik dengan persentase $80 \%$ dimana skor totalnya 483. Ini artinya bahwa Persepsi petani kucai mitra terhadap proses kemitraan dengan Lembaga Keuangan "Bank BRI" memberikan kesan baik.

\section{Analisis Pendapatan Usahatani Antara Petani Kucai Mitra Dengan Petani Kucai Non- Mitra}

\section{Biaya Usahatani}

a. Biaya Tetap

Hasil biaya tetap yang di perhitungkan dalam penelitian ini diambil dari responden yaitu petani kucai mitra dengan petani kucai mandiri selama satu musim tanam atau satu bulan di Desa Kranggan, Pojok, Garum. Dari tabel dapat diketahui biaya tetap total petani mitra yaitu Rp. 1.1628.000 dengan rata-rata Rp.58.400, sedangkan biaya tetap total petani kucai mandiri yaitu Rp. 4.491.242 dengan rata-rata Rp. 67.033. Sehingga dapat diketahui juga biaya pajak lahan yang ditanggung petani mitra selama sebulan yaitu Rp.15.650 selama satu musim tanam, sedangkan untuk petani mandiri biaya pajak lahan yang ditanggung yaitu sebesar Rp. 14.776 dalam satu musim tanam. Dalam satu musim tanam atau satu bulanya biaya tetap total petani mitra lebih kecil dari pada biaya tetap total petani mandiri, hal tersebut disebabkan karena pajak lahan pada petani mitra lebih kecil dari biaya pajak lahan petani mandiri. 
Lintar Brillian Pintakami \& Muttia Yan Asdasiwi, 2020. Analisis Pola Kemitraan Agribisnis Di Kampung Kucai, Dusun Kranggan, Kecamatan Garum, Kabupaten Blitar.

Journal Viabel Pertanian. (2020), 14(1)21-36

Sebagian besar kepemilikan lahan petani kucai mitra dan petani kucai mandiri merupakan lahan milik sendiri. Hal tersebut dikarenakan minimnya lahan sawah dan memanfaatkan lahan pekarangan yang awalnya tidak bernilai ekonomis menjadi memiliki nilai ekonomis dengan digunakannya sebagai media tanam budidaya kucai oleh petani.

\section{b. Biaya Variabel}

Dalam penelitian ini biaya variabelnya yaitu pupuk kandang, pupuk organik, npk, bibit, dan polybag. Diketahui total biaya variabel petani kucai mitra yaitu Rp.31.100 dengan rata-rata 1.555, sedangkan untuk petani mandiri yaitu Rp. 816.350 dengan ratarata 12.184. Maka dapat disimpulkan biaya variabel petani kucai mitra lebih kecil dari biaya variabel petani kucai mandiri

Namun diketahui, pada petani mitra tidak mengeluarkan biaya benih, pupuk organik, dan polybag karena kebutuhan tersebut telah diberikan bantuan oleh Lembaga Keuangan "Bank BRI". Sedangkan untuk petani kucai mandiri tidak mendapatkan bantuan tersebut. Pemberian pupuk organic tersebut karena diharapkan petani kucai mitra dapat menghasilkan kucai organik tanpa bahan kimia.

\section{c. Biaya Total}

Biaya total yaitu keseluruhan biaya yang digunakan dalam proses produksi usahatani. Diketahui dari hasil penjumlahan biaya tetap dan biaya variabel maka biaya total petani kucai mitra yaitu Rp. 1.199.100 dengan rata-rata Rp. 59.925 sekali musim tanam, sedangkan biaya total petani kucai mandiri yaitu Rp. 5.307.592 dengan rata-rata Rp. 79.217 sekali musim tanam. Pada tabel 2 menunjukkan biaya total yang di keluarkan oleh petani kucai mandiri lebih besar dibanding biaya total petani mitra, perbedaan biaya total antara petani kucai mitra dengan mandiri tersebut dikarenakan pada petani mitra mendapatkan bantuan berupa bibit, pupuk dan alat pertanian sedangkan petani mandiri tidak.

Tabel 2.Rata-Rata Biaya Total Per Musim Tanam Petani Kucai Mitra Dan Petani Kucai Mandiri di Desa Kranggan, Pojok, Garum

\begin{tabular}{|r|lccc|}
\hline No. & \multicolumn{1}{|c|}{ Rincian Biaya } & Petani Kucai Mitra & Petani Kucai Mandiri \\
\hline $\mathbf{1}$ & Biaya Tetap (Rp) & 42.750 & \\
\hline & Biaya Alat & 15.650 & 52.257 \\
& Pajak Lahan & $\mathbf{5 8 . 4 0 0}$ & 14.776 \\
& Jumlah Biaya Tetap & & $\mathbf{6 7 . 0 3 3}$ \\
\hline $\mathbf{2}$ & Biaya Variabel (Rp) & - & 1.351 \\
& Pupuk Organik & 765 & 287 \\
& Pupuk Kandang & 760 & 800 \\
& NPK & - & 8.000 \\
& Bibit & - & 1.746 \\
& Polibag & $\mathbf{1 . 5 2 5}$ & $\mathbf{1 2 . 1 8 4}$ \\
\hline \multicolumn{2}{|r|}{ TOTumlah Biaya Variabel } & $\mathbf{5 9 . 9 2 5}$ & $\mathbf{7 9 . 2 1 7}$ \\
\hline
\end{tabular}

Sumber : Data Primer Diolah, 2020

\section{d. Penerimaan Usahatani Kucai}

Penerimaan usahatani yaitu hasil yang diperoleh petani dari jumalah produksi. Penerimaan petani kucai diperoleh dari hasil penjualan panen petani. Penerimaan pada penelitian ini dapat diketahui dengan menghitung hasil penerimaan petani kucai mitra dan petani kucai mandiri selama satu musim tanam yaitu satu bulan. Penerimaan dapat diketahui dengan menghitung jumlah total hasil produksi dikalikan harga yang telah 
Lintar Brillian Pintakami \& Muttia Yan Asdasiwi, 2020. Analisis Pola Kemitraan Agribisnis Di Kampung Kucai, Dusun Kranggan, Kecamatan Garum, Kabupaten Blitar. Journal Viabel Pertanian. (2020), 14(1)21-36

ditentukan. Berikut rata-rata penerimaan petani kucai mitra dan mandiri per musim tanam:

Tabel 3. Rata-Rata Penerimaan Petani Kucai Mitra Dan Mandiri Per Musim Tanam

\begin{tabular}{|l|l|c|c|}
\hline No. & \multicolumn{1}{|c|}{ Uraian } & Petani Kucai Mitra & Petani Kucai Mandiri \\
\hline 1. & Luas Lahan & $250 \mathrm{~m}^{2}$ & $250 \mathrm{~m}^{2}$ \\
\hline 2. & Produksi & $99 \mathrm{Kg}$ & $77 \mathrm{Kg}$ \\
\hline 3. & Harga & Rp. 5.000 & Rp. 5.000 \\
\hline 4. & Penerimaan & Rp. 495.000 & Rp. 385.000 \\
\hline
\end{tabular}

Sumber : Data Primer Diolah, 2020

Dari tabel 3, dapat diketahui rata-rata hasil produksi kucai untuk petani mitra sebesar Rp. 99/kg, dan untuk petani kucai mandiri sebesar Rp. 77/kg. Perbedaan hasil produksi dari petani kucai mitra dan petani kucai mandiri menjadi faktor besarnya penerimaan petani responden. Hasil Produksi kucai petani mitra lebih besar dari petani kucai mandiri dikarenakan berbagai faktor diantaranya petani kucai mitra mendapatkan binaan dari Lembaga Keuangan "Bank BRI" .

\section{e. Pendapatan Usahatani Kucai}

Pendapatan usahatani merupakan selisisih dari penerimaan dan total biaya usahatani kucai. Pendapatan usahatani bergantung pada besar kecilnya penerimaan dan total biaya. Maka usahatani dikatakan berhasil jika pendapatan yang diperoleh lebih besar dari jumlah total biaya yang sudah dikeluarkan dalam berusahatani. Hasil pendapatan yang diperoleh petani kucai mitra ini lebih besar dibanding petani kucai mandiri dikarenakan total biaya pengeluaran petani mitra lebih kecil dari pada total biaya pengeluaran petani mandiri. Hal tersebut dikarenakan petani mitra memperoleh bantuan bibit, pupuk, dan alat pertanian sehingga dapat mengurangi biaya yang di keluarkan oleh petani kucai.Berikut rata-rata pendapatan petani kucai mitra dan petani kucai mandiri : Tabel 4.Rata-Rata Pendapatan Petani Kucai Mitra Dan Petani Kucai Mandiri

\begin{tabular}{|c|l|c|c|c|}
\hline No. & \multicolumn{1}{|c|}{ Rincian } & Penerimaan & Total Biaya & Pendapatan \\
\hline 1. & Petani Kucai Mitra & 495.000 & 59.925 & 435.075 \\
\hline 2. & Petani Kucai Mandiri & 385.000 & 79.217 & 305.783 \\
\hline
\end{tabular}

Sumber : Data Primer Diolah, 2020 


\section{Uji Beda Rata-rata \\ T-Test}

[DataSet0]

\begin{tabular}{|c|c|c|c|c|c|}
\hline \multicolumn{6}{|c|}{ Group Statistics } \\
\hline & Kategori & $N$ & Mean & Std. Deviation & $\begin{array}{l}\text { Std. Error } \\
\text { Mean }\end{array}$ \\
\hline \multirow[t]{2}{*}{ Pendapatan } & 1 & 20 & 433045.00 & 37966.275 & 8489.517 \\
\hline & 2 & 67 & 368662.81 & 77597.977 & 9480.102 \\
\hline
\end{tabular}

\begin{tabular}{|c|c|c|c|c|c|c|c|c|c|c|}
\hline \multicolumn{11}{|c|}{ Independent Samples Test } \\
\hline & & \multicolumn{2}{|c|}{$\begin{array}{l}\text { Levene's Test for Equality of } \\
\text { Variances }\end{array}$} & \multicolumn{7}{|c|}{ t-test for Equality of Means } \\
\hline & & \multirow[b]{2}{*}{$\mathrm{F}$} & \multirow[b]{2}{*}{ Sig. } & \multirow[b]{2}{*}{$t$} & \multirow[b]{2}{*}{ df } & \multirow[b]{2}{*}{ Sig. (2-tailed) } & \multirow[b]{2}{*}{$\begin{array}{c}\text { Mean } \\
\text { Difference }\end{array}$} & \multirow[b]{2}{*}{$\begin{array}{l}\text { Std. Error } \\
\text { Difference }\end{array}$} & \multicolumn{2}{|c|}{$\begin{array}{l}\text { 95\% Confidence Interval of the } \\
\text { Difference }\end{array}$} \\
\hline & & & & & & & & & Lower & Upper \\
\hline Pendapatan & $\begin{array}{l}\text { Equal variances } \\
\text { assumed }\end{array}$ & 12.957 & .001 & 3.574 & 85 & .001 & 64382.194 & 18013.223 & 28567.080 & 100197.308 \\
\hline & $\begin{array}{l}\text { Equal variances not } \\
\text { assumed }\end{array}$ & & & 5.059 & 66.266 & .000 & 64382.194 & 12725.731 & 38976.357 & 89788.031 \\
\hline
\end{tabular}

\footnotetext{
SAVE OUTFILE='D: Untitledl. sav'

/COMPRESSED.

SAVE OUTFILE=' F: \Untitledl. sav'

/COMPRESSED.
}

Gambar 1. Hasil statistik spss uji beda rata- rata

Sumber : Data Primer Diolah, 2020

Diketahui pada tabel uji beda rata-rata diatas nilai Levene's Test for Equality of Variances pada F hit 12,957 > 0,05, maka H0 ditolak HA diterima, maka dapat dikatakan ada perbedaan pendapatan antara petani kucai mitra dan petani kucai mandiri. Pada $t$ hit pada Equal variances not assumed 5,059 > 0,05 maka HA diterima dan H0 ditolak, maka dapat dikatakan terdapat perbedaan nyata antara pendapatan petani kucai mitra dan petani kucai mandiri.Dan dapat dilihat pada Probabilitas atau taraf signifikan pada tabel diatas yaitu sebesar $0,01<0,05$, maka $\mathrm{H} 0$ ditolak, artinya terdapat perbedaan antara petani kucai mitra dan petani kucai mandiri.

\section{KESIMPULAN}

Kemitraan yang telah dijalankan oleh Petani Kucai Mitra dengan Lembaga Keuangan "Bank BRI" yaitu dengan pola kemitraan inti -plasmadimana petani kucai dengan pendapatan ekonomi yang rendah mendapatkan bantuan berupa bibit, pupuk organik, dan alat pertanian. Kemitraan antara Petani Kucai Mitra dengan Lembaga Keuangan "Bank BRI" telah berjalan selama satu tahun. Selama satu tahun petani kucai mitra tersebut diberikan binaan oleh "Bank BRI" untuk mengelola usahataninya dan Petani Kucai Mitra juga harus memiliki tabungan hasil panennya selama satu bulan.

Persepsi Petani Kucai Mitra terhadap kemitraan dengan Lembaga Keuangan "Bank BRI" memiliki kategori sangat baik dengan persentase 80\%, maka dapat ditarik kesimpulan persepsi petani kucai mitra terhadap proses kemitraan dengan Lembaga 
Lintar Brillian Pintakami \& Muttia Yan Asdasiwi, 2020. Analisis Pola Kemitraan Agribisnis Di Kampung Kucai, Dusun Kranggan, Kecamatan Garum, Kabupaten Blitar.

Journal Viabel Pertanian. (2020), 14(1)21-36

Keuangan "Bank BRI" mendapatkan kesan sangat baik. Dari 10 variabel persepsi yang dianalisis, maka hasil penelitian lapang menunjukkan persepsi petani kucai mitra menyatakan 8 variabel sangat baik, dan persepsi petani kucai mitra menyatakan 2 variabel cukup baik.

Berdasarkan dari hasil analisis usahatani pendapatan petani kucai mitra memperoleh hasil lebih besar dibandingkan hasil pendapatan yang diperoleh petani kucai mandiri. Rata-rata pendapatan yang diperoleh petani kucai mitra Rp. 435.075dalam sekali panen, dan rata-rata pendapatan petani kucai mandiri Rp. 305.783dalam sekali panen. Selanjutnya dari nilai $\mathrm{F}$ hit sebesar 12,957> 0,05 maka H0 ditolak HA diterima, maka dapat dikatakan ada perbedaan pendapatan antara petani kucai mitra dan petani kucai mandiri. Sedangkan untuk nilai t hit 5,059 > 0,05, maka HA diterima dan H0 ditolak, maka dapat dikatakan terdapat perbedaan nyata antara pendapatan petani kucai mitra dan petani kucai mandiri. Dan untuk nilai Probabilitas atau taraf signifikan pada tabel diatas yaitu sebesar $0,01<0,05$ maka $\mathrm{H} 0$ ditolak, artinya terdapat perbedaan antara petani kucai mitra dan petani kucai mandiri.

Maka dapat diambil kesimpulan terdapat perbedaap antara pendapatan petani kucai mitra dengan pendapatan kucai mandiri. Perbedaan tersebut disebabkan Karena hasil produksi petani kucai mitra lebih besar dibanding hasil produksi kucai mandiri. Adanya binaan dari Lembaga Keuangan Bank BRI tersebut sehingga produksi kucai yang diperoleh petani kucai mitra lebih unggul dibanding petani kucai mandiri yang tidak mendapat binaan. Selain itu biaya usahatani kucai untuk petani mitra mendapat bantuan dari Lembaga Keuangan "Bank BRI" sehingga meminimalisir pengeluaran modal oleh petani , sedangkan untuk petani kucai mandiri tidak dapat.

\section{DAFTAR PUSTAKA}

Amirin, T. M. (2011). Populasi dan sampel penelitian 4: Ukuran sampel rumus Slovin. Di unduh, 21.

Ashari, S. T. (2012). Potensi dan Prospek Pemanfaatan Lahan Pekarangan Untuk Mendukung Ketahanan Pangan. Jakarta: Pusat Sosial Ekonomi dan Kebijakan Pertanian Press.

Bitzer, V., Glasbergen, P. and Arts, B., 2013. Exploring the potential of intersectoral partnerships to improve the position of farmers in global agrifood chains: findings from the coffee sector in Peru. Agriculture and Human Values, 30(1), pp.5-20.

Carter, W. K., \& Usry, M. F. (2009). Akuntansi biaya. Jakarta: Salemba Empat.

CNN Indonesia. (2018). BPS Sebut Luas Lahan Pertanian Kian Menurun. https://www.cnnindonesia.com/ekonomi/20181025153705-92-341433/bps-sebutluas-lahan-pertanian-kian-menurun. [Online] Diakses pada 07 Januari 2018.

Dahniar, F. (2011). Hubungan Antara Persepsi Terhadap Word Of Mouth (Wom) Dengan Intensi Membeli Makanan Vegetarian Pada Mahasiswa Fakultas Psikologi Universitas Diponegoro. Semarang : Universitas Diponegoro.

Dewi, M. A. R. (2012). Analisis Efisiensi Teknis Penggunaan Faktor Produksi Pada Usahatani Jagung (Zea Mays)(Studi Kasus Desa Kramat, Kecamatan Bangkalan, Kabupaten Bangkalan, Madura) (Doctoral dissertation, Universitas Brawijaya).

Fahrudin, D. (2010). Pola Kemitraan Antara PT. Bisi Internasional, Tbk dengan Petani Buncis di Desa Bendosari Kecamatan Pujon Kabupaten Malang. Malang: Skripsi Fakultas Pertanian Universitas Brawijaya. 
Lintar Brillian Pintakami \& Muttia Yan Asdasiwi, 2020. Analisis Pola Kemitraan Agribisnis Di Kampung Kucai, Dusun Kranggan, Kecamatan Garum, Kabupaten Blitar.

Journal Viabel Pertanian. (2020), 14(1)21-36

Fitriza, Y. T., Haryadi, F. T., \& Syahlani, S. P. (2012). Analisis pendapatan dan persepsi peternak plasma terhadap kontrak perjanjian pola kemitraan ayam pedaging di Propinsi Lampung. Buletin Peternakan, 36(1), 57-65.

Gipson, J. D., Hirz, A. E., \& Avila, J. L. (2011). Perceptions and practices of illegal abortion among urban young adults in the Philippines: a qualitative study. Studies in family planning, 42(4), 261-272.

Gregoratti, C. (2011). Global nuts and local mangoes: A critical reading of the UNDP Growing Sustainable Business Initiative in Kenya. Agriculture and Human Values 28: $369-383$.

Lestari M. 2009. Analisis Pendapatan dan Tingkat Kepuasan Peternak Plasma Terhadap Pelaksanaan Kemitraan Ayam Broiler (Studi Kasus Kemitraan PT. X di Yogyakarta) (skripsi). Bogor: Fakultas Ekonomi dan Manajemen, Institut Pertanian Bogor.

Musoleha, T., Hasanuddin, T., \& Listiana, I. (2014). Persepsi Masyarakat terhadap Program Kemitraan dan Bina Lingkungan (Pkbl) PTPN VII Unit USAha Rejosari Kecamatan Natar Kabupaten Lampung Selatan. Jurnal Ilmu-Ilmu Agribisnis, 2(4), 390-398.

Paeru, R. H., Dewi, T. Q., Ahli, P., \& Sunarjono, H. H. (2015). Panduan Praktis Bertanam Sayuran di Pekarangan. Penebar Swadaya Grup.

Pintakami, L. B. (2018). Analisis Kontribusi Gender Dalam Budidaya Tanaman Kucai Skala Rumah Tangga Di Lahan Pekarangan. VIABEL: Jurnal Ilmiah Ilmu-Ilmu Pertanian, 12(1), 27-48.

Pintakami, L.B., Yuliati, Y. and Purnomo, M. (2013). Keterlibatan Perempuan Tani Pada Program Pengelolaan Hutan Bersama Masyarakat (PHBM) Dalam Rangka Mencapai Kesejahteraan Rumah Tangga (Studi Kasus Di Desa Bayem, Kecamatan Kasembon, Kabupaten Malang). Indonesian Journal of Women's Studies, 1(1).

Rankin, M., Nogales, E.G., Santacoloma, P., Mhlanga, N. and Rizzo, C. (2016). Publicprivate partnerships for agribusiness development. Rome: FAO.

Ratih, A. (2011). Analisis Pelaksanaan Kemitraan Dalam Agroindustri Apel Antara UD. Bagus Agriseta Mandiri Dengan Petani Apel Di Desa Bumiaji, Kecamatan Bumiaji, Kota Wisata Batu (skripsi). Malang : Fakultas Pertanian Universitas Brawijaya.

Santoso, P., Suryadi, A., Subagyo, H., \& Latulung, B. V. (2014). Dampak teknologi sistem usaha pertanian padi terhadap peningkatan produksi dan pendapatan usahatani di Jawa Timur. Jurnal Pengkajian dan Pengembangan Teknologi Pertanian, 8(1).

Setiawati, W., Murtiningsih, R., Sopha, G. A., \& Handayani, T. (2007). Budidaya Tanaman Sayuran. Balai Penelitian Tanaman Sayuran. Bandung.

Soekartawi, S. (2012). Beberapa Hal Yang Perlu Diperhatikan Dalam Melakukan Analisis Sistem Agroindustri Terpadu. Jurnal Agribisnis dan Ekonomi Pertanian, 1(2).

Sugiyono. (2010). Statistika Untuk Penelitian. Bandung: Alfabeta. 
Lintar Brillian Pintakami \& Muttia Yan Asdasiwi, 2020. Analisis Pola Kemitraan Agribisnis Di Kampung Kucai, Dusun Kranggan, Kecamatan Garum, Kabupaten Blitar. Journal Viabel Pertanian. (2020), 14(1)21-36

Sutopo. (2018). Penentuan Jumlah Sampel dalam Penelitian. STIE Dharmaputra Semarang.

Wahyu, P. (2010). Studi Pola Kemitraan Usahatani Benih Jagung Pada CV. Riawan Tani Di Desa Sawentar Kecamatan Kanigoro Kabupaten Blitar (skripsi). Malang: Fakultas Pertanian Universitas Brawijaya.

Wati, I. (2017). Analisis Biaya dan Pendapatan Usaha Tani dengan Sistem Kondomisasi pada Buah Kakao (Theobroma cacao. L)(Studi Kasus di Kelurahan Noling, Kecamatan Bupon, Kabupaten Luwu). Jurnal Pertanian Berkelanjutan, 3(3), 50-60.

Yulida, R. (2013). Kontribusi Usahatani Lahan Pekarangan terhadap Ekonomi Rumah Tangga Petani di Kecamatan Kerinci Kabupaten Pelalawan. IJAE (Jurnal Ilmu Ekonomi Pertanian Indonesia), 3(2), pp.135-154. 